\title{
Individual heat generation to sustainable development in local scale
}

\author{
Michat Kaczmarczyk*, Anna Sowiżdżał, Barbara Tomaszewska \\ AGH University of Science and Technology, Faculty of Geology, Geophysics and Environmental \\ Protection, Department of Fossil Fuels
}

\begin{abstract}
The problem of air pollution, resulting from the occurrence of so-called low emission concerns many localities in Poland and Europe. The main reasons for such a situation is burning of fuels for central heating and domestic hot water in buildings, as well as the burning of fuels in the transport sector. It should be noted that in the case of building heat management, frequently this is the result of a lack of access to the heating and gas network. This is one of the reasons hindering sustainable development opportunities. The article presents calculations of combustion products emissions into the atmosphere (TSP, $\mathrm{CO}, \mathrm{NO}_{\mathrm{x}}, \mathrm{SO}_{\mathrm{x}}$ ) from individual heat sources in households for the commune which does not have the above mentioned infrastructure. The purpose of the analysis was to present the environmental impact of changes in the structure of heat generation and improvement of the effectiveness of the devices used. In addition, the proposed calculation model can be used by municipalities, allowing the assessment of ecological effects of undertaken actions.
\end{abstract}

\section{Introduction}

Pollution of the environment, which the modern society is struggling with is mainly related to the energy sector. Modern approach to this issue requires the increasingly important problem of the occurrence of so-called low emissions. This concept has no authority in Polish legislation, however, it has been precisely formulated in literature [1] and defined as the emission of combustion products form solid, liquid and gaseous fuels into the atmosphere from emission sources (emitters) at an altitude of no more than $40 \mathrm{~m}$. Definition stands out communication emission, emission resulting from heat generation for the purposes of central heating and domestic hot water as well as industrial emissions. Combustion products that affect the occurrence of low emissions include gases: carbon dioxide $\mathrm{CO}_{2}$, carbon monoxide $\mathrm{CO}$, sulfur dioxide $\mathrm{SO}_{2}$, nitrogen oxides $\mathrm{NO}_{x}$, polycyclic aromatic hydrocarbons, e.g. benzo(a)pyrene and dioxins, as well as heavy metals (lead, arsenic, nickel, cadmium) and particulate matter PM10, PM2.5. The lack of authorization in Polish legislation does not mean, however, that the issue of low emission is not commented [2-3] also at the global level [4-7].

The air quality monitoring system in Poland consists of various types of measuring stations. Studies are also carried out based on other monitoring techniques as modeling,

\footnotetext{
* Corresponding author: mkz@agh.edu.pl
} 
passive methods, supplementary tests [8]. Research and assessment of air quality in Poland, in accordance with the Environmental Protection Law [9], are carried out by the Voivodship Inspectorates for Environmental Protection as part of the State Environmental Monitoring (SEM). The average annual standards for individual pollutants are respectively: for PM10 $40 \mu \mathrm{g} / \mathrm{m}^{3}$, for PM2.5 - $25 \mu \mathrm{g} / \mathrm{m}^{3}$, for benzo(a)pyrene $-1 \mathrm{ng} / \mathrm{m}^{3}$, for $\mathrm{SO}_{2}$ and $\mathrm{NO}_{\mathrm{x}}-20 \mu \mathrm{g} / \mathrm{m}^{3}$ (applies permissible levels due to plant protection), for $\mathrm{NO}_{2}-40 \mu \mathrm{g} / \mathrm{m}^{3}$.

The results of the annual assessment of air quality for 2017 in Poland do not differ materially from those obtained in earlier years. In comparison to 2016 there is a slight increase of the number of exceedances of standards established for PM2.5 and PM10. For $\mathrm{B}(\mathrm{a}) \mathrm{P}$, the highest annual average values were obtained in the provinces: Małopolska (22.7, 14.6 and $\left.10.0 \mathrm{ng} / \mathrm{m}^{3}\right)$, Silesia $\left(16.0,14.5\right.$ and $\left.12.3 \mathrm{ng} / \mathrm{m}^{3}\right)$ and Lower Silesia $\left(15.9 \mathrm{ng} / \mathrm{m}^{3}\right)$. In the case of PM10, the highest average annual concentration was recorded at urban background stations in the Małopolska $\left(64.3 \mu \mathrm{g} / \mathrm{m}^{3}\right)$ and Silesia $\left(55.6 \mu \mathrm{g} / \mathrm{m}^{3}\right)[10]$.

The main source of low emission occurrence are heat generation processes for the needs of central heating and domestic hot water in households [10-12]. With such a defined problem, it is necessary to search for solutions in the modernization of heat sources, especially in areas where heating or gas network infrastructure does not occur. The natural direction seems to be increasing the use of renewable energy sources for this purpose, whose resources in many regions of Poland are appropriate, although their use is still low [13-14].

In this paper, an attempt was made to answer the question posed by municipality authorities, how to limit the negative impact of individual heat generation on the environment [15]. The calculations performed have been carried out for an exemplary rural commune that does not have heating and gas network infrastructure. Such a variant was adopted due to the lack of access of residents of rural communes to the abovementioned infrastructure, and consequently to the necessity of using primarily fossil fuels for heating purposes. Statistical data on the population using gas from the network and gas consumption per capita indicate that $52.1 \%$ of the population benefited from gas in Poland. This value should be considered as low. Additionally, taking into account the fact that in $71.2 \%$ these were urban areas, and only in $23.3 \%$ rural areas the conclusion of limited access to the gas network is obvious [16]. The lack of local heating networks was considered as the second element excluding the municipality from the possibility of sustainable development and improvement of air quality. Statistical data on the heat network density in 2017 in Poland indicate its average length in relation to $100 \mathrm{~km}^{2}$ area of $8.1 \mathrm{~km}$. The most important fact is that district heating networks occur mainly in urban areas, which accounted for $98.3 \%$. Unfortunately, fuel used in existing heat plants are usually solid fuels $-66.2 \%$ [16].

It is worth noting that there are 1555 rural communes in Poland, which in relation to the above data shows the scale of the problem. As it was mentioned, the lack of access to the network infrastructure makes it necessary to use other energy carriers. The answer to the question, what are the carriers, are statistical data published by the Central Office of Building Control [17], which indicate the number of construction permits issued in Poland in 2018 for 196322 (226 469 facilities). In this pool, residential buildings constituted 98915 , out of which $94.7 \%$ were single-family houses. Unfortunately, as reported [18], 65\% of newly constructed buildings are equipped with solid-fuel boilers.

\section{Methodology}

Analytical work was carried out for a representative theoretical rural commune with a population of 8000 . The average number of people in the household was taken as 3.4 [19], which allowed to calculate the total number of households in the area of the commune, which amounted to 2353 . According to the data published by the Central Statistical Office [18], the average household area in Poland in the rural region is $108.310 \mathrm{~m}^{2}$. The average energy 
demand is $216 \mathrm{kWh} / \mathrm{m}^{2 *}$ year [20]. This information made it possible to calculate the total demand of the analyzed municipality for heat to central heating and domestic hot tap water preparation at the level of $198150776 \mathrm{MJ}$.

Subsequently, calculations of emission of pollutants into the atmosphere were made. The first stage was to establish the structure of energy carriers and heating devices used. The analysis was carried out for 6 models. Model 1 assumed $70 \%$ of coal, $25 \%$ of biomass and $5 \%$ of fuel oil used. In the model 2 it was $70 \%$ of biomass, $25 \%$ of coal and $5 \%$ of fuel oil. Model 3 was characterized by used of coal in $47.5 \%$, biomass in $47.5 \%$ and fuel oil in $5 \%$. The same structure as in model 3 was used in model 4 , but the efficiency of heating devices has been increased by $5 \%$. In model 5 the share of coal was assumed at $40 \%$, the biomass at $40 \%$, fuel oil at $5 \%$ and heat pumps at $15 \%$. The last variant of calculations (model 6 ) based on $40 \%$ share of coal, $40 \%$ biomass, $5 \%$ fuel oil, $15 \%$ heat pumps and $5 \%$ increase in efficiency of heating devices.

Each of the analyzed energy carriers was assigned heating values and efficiency of heating devices (in the case of oil boilers including traditional and condensing boilers) [21]. In total, 6 types of biomass (pellet, dry wood, straw briquette, wood briquette, rape straw, corn straw), 3 types of coal (eco-pea coal, nut-type cole, culm), 2 types of fuel oil (light fuel oil, heavy) were analyzed. fuel oil) and 3 types of heat pumps (air/water, brine/water with vertical heat exchanger, brine/water with a horizontal heat exchanger). For individual groups (biomass, coal, fuel oil and heat pumps), arithmetic averages were calculated and then a percentage share was assigned to the analyzed model. The emission of pollutants into the atmosphere was calculated on the basis of the National Center for Emissions Management (KOBIZE) guidelines, on emission factors for fuel combustion in boilers with a nominal thermal capacity of $5 \mathrm{MW}$ [22]. Calculations were made according to the equations:

$$
B=\frac{Q \cdot A}{\eta \cdot W_{O}}
$$

where:

$B$ - amount of fuel $\left[\mathrm{m}^{3}\right]$ or $[\mathrm{kg}]$,

$Q$ - amount of produced energy [MJ/m $\left.\mathrm{m}^{2} \mathrm{rok}\right]$, assumed $1 \mathrm{MJ} / \mathrm{m}^{2} \mathrm{rok}$,

$A$ - heated area $\left[\mathrm{m}^{2}\right]$, assumed $1 \mathrm{~m}^{2}$,

$\eta$-boiler efficiency [-],

$W_{O}$ - calorific value of fuel, $\left[\mathrm{MJ} / \mathrm{m}^{3}\right]$ or $[\mathrm{MJ} / \mathrm{kg}]$.

$$
E=B \cdot W
$$

where:

E-emission of pollutants [ $\mathrm{kg}]$,

$B$ - amount of fuel, $\left[\mathrm{m}^{3}\right]$ or $[\mathrm{kg}]$,

$W$ - emission factor [ $\mathrm{kg}]$.

\section{Results of calculations}

The results of the calculations are presented in Figures 1-6. As a baseline model, to which further calculation variants were compared, model 1 was adopted with $70 \%$ share of coal, $25 \%$ share of biomass and $5 \%$ share of fuel oil. The results obtained in model 1 (Fig. 1) 
showed emissions of pollutants to the atmosphere during the year: TSP $-55638.93 \mathrm{~kg}, \mathrm{CO}$ $-234279.93 \mathrm{~kg}, \mathrm{NO}_{\mathrm{x}}-11393.54 \mathrm{~kg}$ and $\mathrm{SO}_{\mathrm{x}}-35190.59 \mathrm{~kg}$.

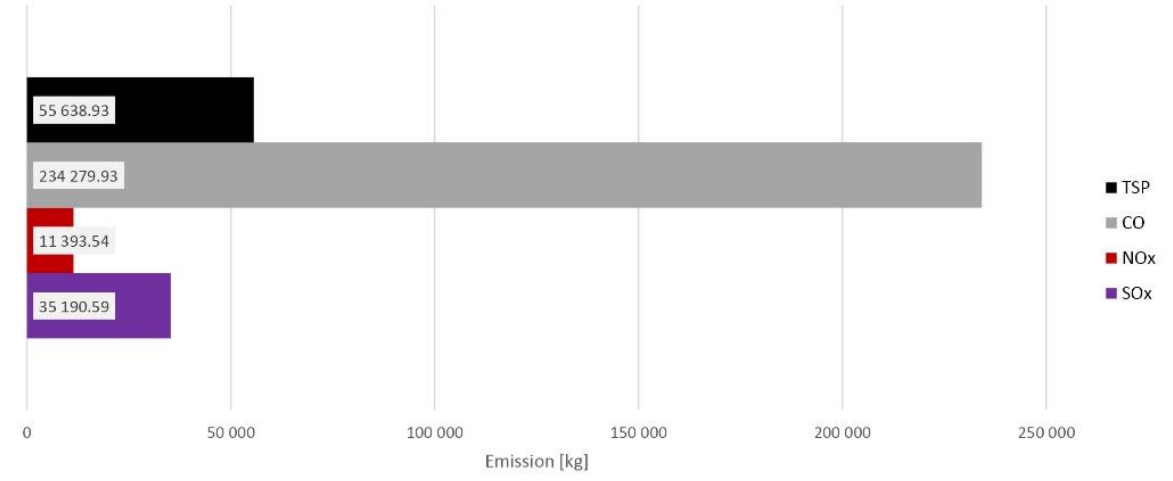

Fig. 1. Annual emission of pollutants in Model 1: $70 \%$ coal, $25 \%$ biomass, $5 \%$ fuel oil.

The results obtained in model 2 (Fig. 2), assuming 70\% share of biomass, $25 \%$ share of coal and $5 \%$ share of fuel oil, indicate a significant reduction of emissions. Annual emission of TSP was calculated at the level of $42155,76 \mathrm{~kg}, \mathrm{CO}-20796.16 \mathrm{~kg}, \mathrm{NO}_{\mathrm{x}}-9412.92 \mathrm{~kg}$ and $\mathrm{SO}_{\mathrm{x}}-14271.17 \mathrm{~kg}$. In model 3 (Fig. 3), an equal share of coal and biomass utilization at the level of $47.5 \%$ was assumed, with a $5 \%$ share of fuel oil. The obtained results are not as optimistic as in the case of model 2: TSP - $48897.34 \mathrm{~kg}, \mathrm{CO}-221122.55 \mathrm{~kg}, \mathrm{NO}_{\mathrm{x}}-$ $10403.23 \mathrm{~kg}, \mathrm{SO}_{\mathrm{x}}-24730.88 \mathrm{~kg}$.

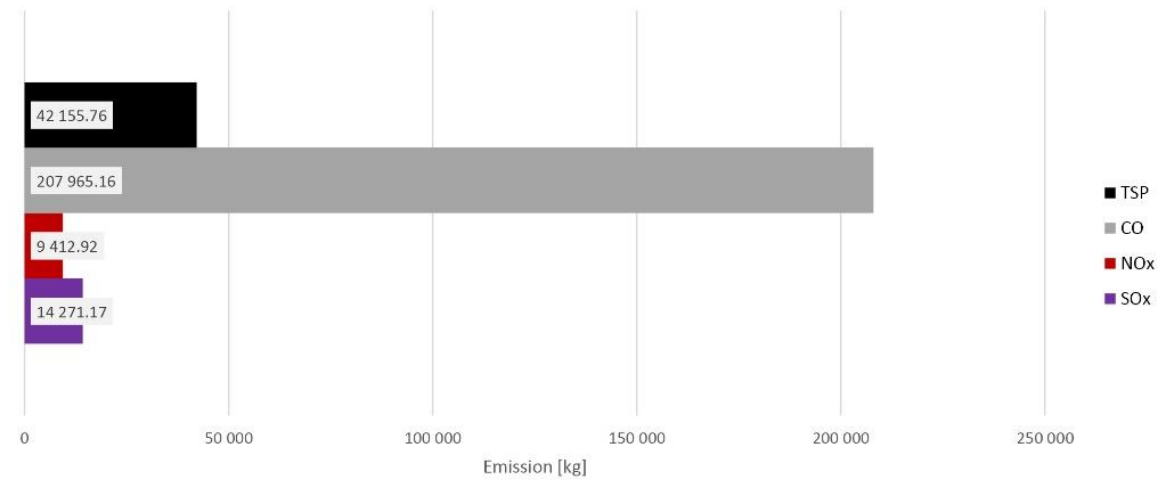

Fig. 2. Annual emission of pollutants in Model 2: $25 \%$ coal, $70 \%$ biomass, $5 \%$ fuel oil.

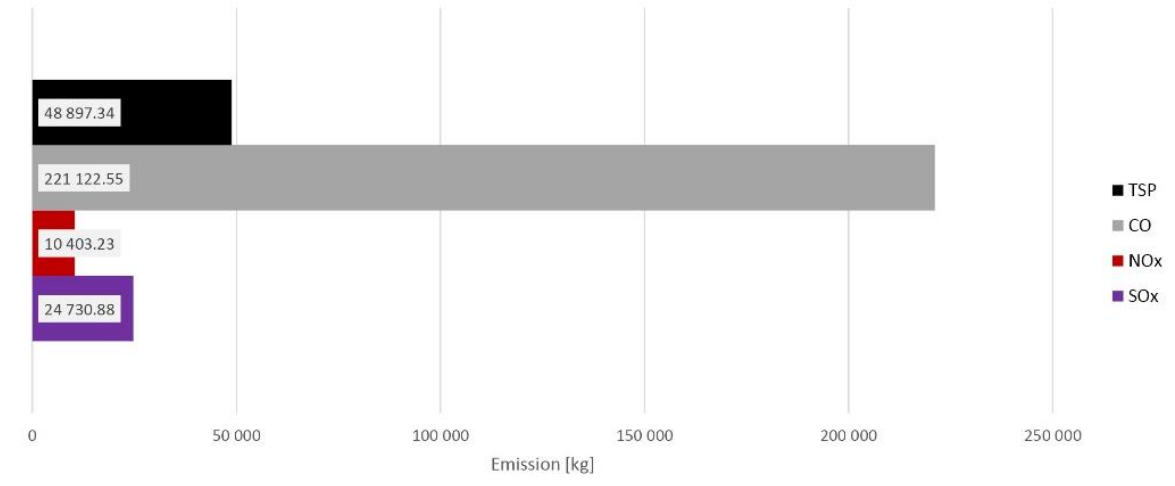

Fig. 3. Annual emission of pollutants in Model 3: $47.5 \%$ coal, $47.5 \%$ biomass, $5 \%$ fuel oil. 
Model 4 (Fig. 4), based on the same assumptions as model 3, but supplemented with an increase heating devices efficiency by $5 \%$. The assumed value of efficiency increase is relatively low, however it results from taking into account efficiency of the entire central heating and domestic hot water installation (efficiency of transmission, regulation and use), not only the heat generation efficiency. Nevertheless, the obtained results indicate the desired effect in comparison to model 3: TSP - $45277.75 \mathrm{~kg}, \mathrm{CO}-206481.91 \mathrm{~kg}, \mathrm{NO}_{\mathrm{x}}-9776.24$ $\mathrm{kg}, \mathrm{SO}_{\mathrm{x}}-23296.19 \mathrm{~kg}$.

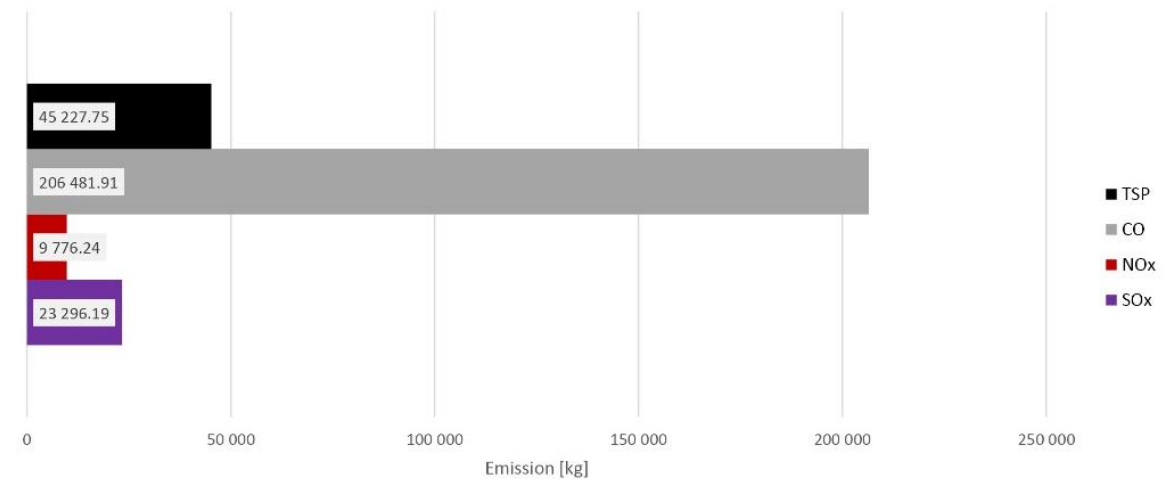

Fig. 4. Annual emission of pollutants in Model 4: 47.5\% coal, $47.5 \%$ biomass, $5 \%$ fuel oil and 5\% growth of the devices efficiency.

Models 5 and 6 include a 15\% share of heat pumps. This value results mainly from the development of the heat pump market in Poland. The calculation results for model 5 (Fig. 5) and 6 (Fig. 6) show a higher level of pollutants reduction for TSP, $\mathrm{CO}$ and $\mathrm{NO}_{\mathrm{x}}$ than all other analyzed models. Only in the case of $\mathrm{SO}_{x}$, the values are preferable to calculated in model 2. In the model 5 emission of TSP is $41209.06 \mathrm{~kg}, \mathrm{CO}-186236.68 \mathrm{~kg}, \mathrm{NO}_{\mathrm{x}}-8901.08 \mathrm{~kg}$ and $\mathrm{SO}_{\mathrm{x}}-21116.32 \mathrm{~kg}$ while in model 6 emission of TSP is $38118.88 \mathrm{~kg}, \mathrm{CO}-173907.72 \mathrm{~kg}$, $\mathrm{NO}_{\mathrm{x}}-8373.09 \mathrm{~kg}$ and $\mathrm{SO}_{\mathrm{x}} 19908.15 \mathrm{~kg}$.

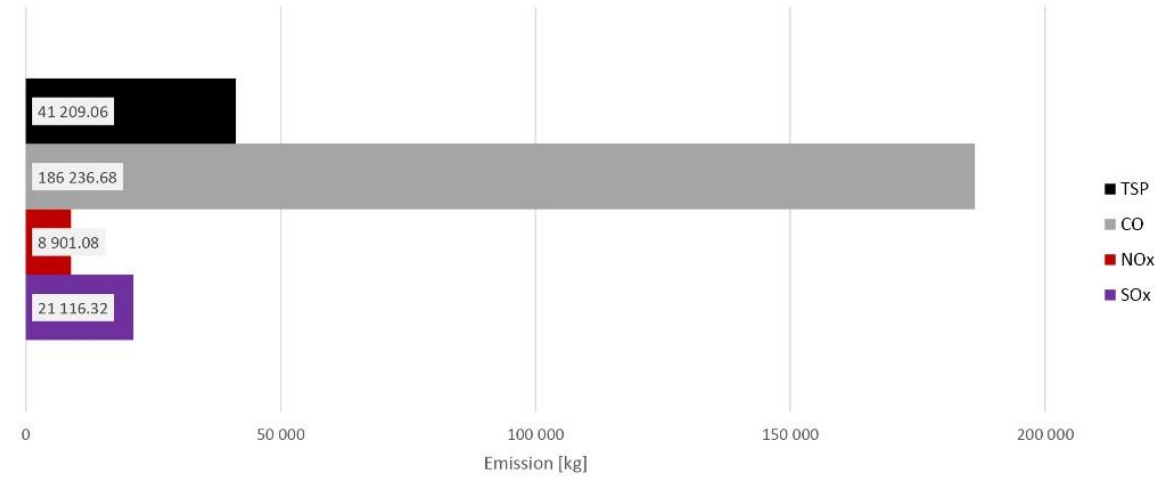

Fig. 5. Annual emission of pollutants in Model 5: $40 \%$ coal, $40 \%$ biomass, $5 \%$ fuel oil, $15 \%$ heat pumps. 


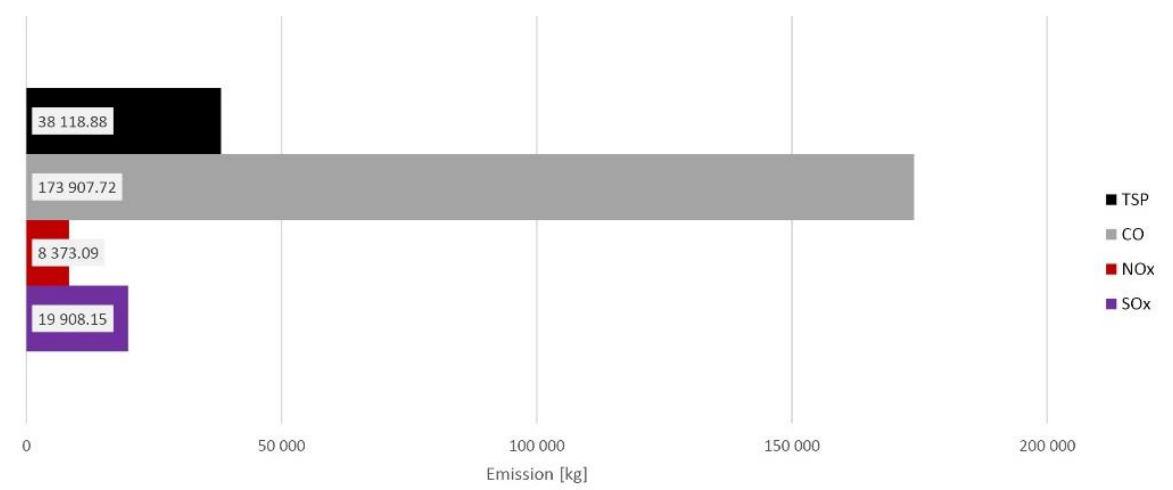

Fig. 6. Annual emission of pollutants in Model 6: $40 \%$ coal, $40 \%$ biomass, $5 \%$ fuel oil, $15 \%$ heat pumps and $5 \%$ growth of the devices efficiency.

\section{Discussion and conclusions}

The occurrence of low emissions in Poland is a common phenomenon, which is confirmed annually by the reports of Chief Inspectorate Of Environmental Protection in Poland and European Environment Agency. The main reason for this state of affairs is the individual combustion of solid fuels for the needs of central heating and domestic hot water. In the case of rural communes, the reasons for this situation should be seen firstly in the lack of infrastructure of the heating and gas network, and secondly in the wealth of the society. The results of the calculations presented in the article clearly indicate that the structure of heat generation based on fossil fuels is the least beneficial from the point of view of environmental protection.

It is impossible to indicate one utilitarian model of conduct for each of the rural communes in Poland, because each of them is characterized by different geographical, topographical, spatial and economic conditions. It is possible, however, to analyze the situation in communes using the calculation model presented in the article to indicate specific actions aimed at improving air quality through a planned change in the structure of heat generation. It should be clearly stated that the results obtained in individual models indicate the legitimacy of increasing the share of the use of renewable energy sources. In addition, building a sustainable energy mix on a local scale, while reducing the share of coal, indisputably contributes to the reduction of pollutant emissions to the environment.

From the models presented in the work follows that the most advantageous solution is the Model 6, although there are already communes in Poland which prohibit the combustion of fossil fuels (excluding natural gas). The first results of these activities will be known after the end of the heating season 2019/2020. Model 6 is characterized by the largest declines in pollutant emissions compared to the baseline Model 1: $43.43 \%$ for $\mathrm{SO}_{\mathrm{x}}, 26.51 \%$ for $\mathrm{NO}_{\mathrm{x}}$, $25.77 \%$ for CO and $31.49 \%$ for TSP. Undoubtedly, this is an evidence of necessity to undertaking activities involving the old boilers replacement for new devices and promoting solutions based on renewable energy sources.

Key conclusions:

- The problem of low emissions is individual heat sources.

- The classification of individual heat sources from the most to the least emission ones is as follows: coal, biomass, fuel oil, heat pumps, natural gas.

- It should be taken into account that the heat pump does not - in fact - emit any pollutants in the workplace. 
- The main problem is the structure of the energy sources used, the efficiency of heating devices is not as important as it is supposed to be.

- Heating installations should be considered not only from the point of view of heat source efficiency, but also heat transfer and its accumulation.

- The wealth of the society is the main problem in reducing low emissions.

The paper has been prepared under the AGH-UST statutory research grant No. 16.16.140.315/05.

\section{Literature}

1. M. Kaczmarczyk (edit), Niska emisja. Od przyczyn występowania do sposobów eliminacji (2015)

2. J.W. Pałasz, Niska emisja ze spalania węgla i metody jej ograniczania (2016)

3. B. Tomaszewska, A. Kasztelewicz, M. Dendys, W. Bujakowski, S. Rahner, M. Hartmann, J. Weinreich, E3S Web of Conferences vol. 66, art. No. 03005 (2018)

4. X. Wnag, J.J. Klemes, X. Dong, W. Fan, Z. Xu, Y. Wang, P.S. Varbanov, Renewable and Sustainable Energy Reviews 105 (2019)

5. M. Ligus, P. Peternek, Energy Procedia 153 (2018)

6. M. Dzikuć, Journal of Cleanet Production 166 (2017)

7. M. Ligus, Energy Procedia 136 (2017)

8. T. Schönfelder (edit), Analiza możliwości ograniczania niskiej emisji ze szczególnym uwzględnieniem sektora bytowo-komunalnego (2011)

9. S. Rahner, I. Winter, M. Hartmann, F. Wittich, A. Kasztelewicz, B. Tomaszewska, L. Pajak, M. Dendys, A. Operacz, M. Mraz, S. Nistor, E3S Web of Conferences vol. 66, art. No. 03004 (2018)

10. Główny Inspektorat Ochrony Środowiska, Państwowy Monitoring Środowiska Inspekcja Ochrony Środowiska, Ocena jakości powietrza w strefach w Polsce za rok 2017 (2018)

11. M. Kaczmarczyk (edit), Niska emisja. Efektywność energetyczna $w$ gminach $i$ samorzadach (2017)

12. European Environment Agency, Air quality in Europe - 2018 report (2018)

13. A. Sowiżdżał, Renewable and Sustainable Energy Reviews 82 (2017)

14. A. Sowiżdżał, A. Chmielowska, B. Tomaszewska, A. Operacz, J. Chowaniec, Arch. Environ. Prot. 3 (2019)

15. M. Kaczmarczyk, A. Sowiżdżał, B. Tomaszewska, Energies 13(2), 454 (2020)

16. Główny Urząd Statystyczny, Infrastruktura komunalna w 2017 r. (2018)

17. Główny Urząd Nadzoru Budowlanego, Ruch budowlany w 2018 r. (2019)

18. A. Dworkowska, Efektywność energetyczna w Polsce. Przeglad 2013. Domy jednorodzinne. Efektywność energetyczna a jakość powietrza (2014)

19. Główny Urząd Statystyczny, Zużycie energii w gospodarstwach domowych $w 2015$ r. (2017)

20. A. Bielewicz, K. Dziamara-Rzucidło, A. Guła, D. Koc, M. Kojs, A. Panek, A. Rajkiewicz, A. Sokulska, D. Staniaszek, M. Walencka, A. Węglarz, E. Zaborowska, M. Zaborowski, Strategia modernizacji budynków: mapa drogowa 2050 (2014)

21. M. Kaczmarczyk, E3S Web of Conferences, vol. 44 art. no. 00062 (2018)

22. Instytut Ochrony Środowiska-Państwowy Instytut Badawczy, Wskaźniki emisji zanieczyszczeń ze spalania paliw. Kotty o nominalnej mocy cieplnej do 5 MW (2015) 